\title{
A guide for the perplexed \\ A student's navigation through Jewish studies in Sweden
}

\author{
NATALIE LANTZ
}

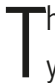

his article presents a student's perspective on Jewish studies in Sweden over the past ten years. By identifying the milestones of her own educational and professional path, the author discusses three questions of particular interest for a student wanting to pursue any kind of Jewish studies in a Nordic country, using Sweden as an example, namely: 1) How to compose a curriculum that leads to doctoral studies? 2) What can be said about the 'identity' of Jewish studies in Sweden? 3) Can a degree in the subject field of choice also lead to a career outside the academic framework?

My article will offer a student's perspective on Jewish studies ${ }^{1}$ in Sweden for the last ten years. I write in the capacity of student representative of the Forum for Jewish Studies (FJS) at Uppsala University (UU) and I have study experiences from three important settings for Jewish studies in Sweden today. ${ }^{2}$ By identifying the milestones in my own educational and professional path, I want to discuss three questions of particular interest for a student wanting to pursue any kind of Jewish studies in a Nordic country, using Sweden as an example:

I. How to compose a curriculum that leads to doctoral studies?

2. What can be said about the 'identity' of Jewish studies in Sweden?

3. Can a degree in the subject field of choice also lead to a career outside the academic framework?

These questions are formulated in general terms due to the interdisciplinary character of Jewish studies: it encompasses a wide range of disciplines such as Jewish history, languages, religion, literature, thought, society, politics and

1 Here I define 'Jewish studies' in the broadest sense, spanning Jewish religion and Jewish civilizations throughout history.

2 Jewish studies at Lund University, classic and modern Hebrew and Hebrew Bible exegesis at Uppsala University and Jewish studies at Paideia - The Institute for Jewish Studies in Sweden. 
culture. Under the generic title 'Jewish studies' we find tracks of quite different nature: courses in Halakbic Midrashim and contemporary Hebrew fiction can be found in the same syllabus, together with courses on Zionism, Shoah or Sephardic studies. The rich variety of research areas are often allowed to undergo cross-fertilization at larger academic institutes where faculties from different departments are brought together to provide the students with a helicopter view of Jewish studies.

Many institutes of Jewish studies around the world offer courses that range from the basic introductory level of a particular topic to more advanced seminars. The student is therefore well informed when it is time to seek advanced knowledge at graduate level, and to prepare for the doctoral level. These academic settings enable the student to navigate the immense landscape of Jewish studies and find a path that leads to a degree, and further, to a profession in fields such as education, communal service, publishing, journalism and public affairs.

In Sweden, the case is different. I will approach the situation by taking you all on my own personal journey through Jewish studies from Lund University, to Uppsala University, to Paideia and via the Hebrew University, back to Uppsala.

\section{How to compose a curriculum that leads to doctoral studies?}

In Sweden we do not (yet) have the infrastructures that institutes specialized in Jewish studies do to allow the students to follow through programmes which are designed to take them from the basic level to doctoral level in Jewish studies. Nevertheless, in Sweden there are many academic disciplines that do lead to the doctoral level and easily could be ascribed to the multi- and cross-disciplinary mishmash also known as 'Jewish studies'. Naturally, these disciplines are scattered across the different universities and their various departments, but it is up to the student and the student's supervisors to make contact with experts from other universities/departments in order to broaden the student's orientation within other fields of Jewish studies.

I will illustrate how I patched my own degree together by combining different courses and programmes, guided by two main interests of mine: language and literature.

After graduating from high school, I knew that modern and classical Hebrew and rabbinic literature would be the cardinal points on my journey into academia. I enrolled at Lund University (LU), the first and - so far - only university in Scandinavia which has established a professorship in Jewish studies. (Unfortunately the third-cycle subject area of Jewish studies is no longer extant 
at LU). Over two semesters we combined introductory courses in Talmud and Midrash, Jewish memory, Jewish faith and tradition with courses in modern Hebrew.

On one occasion, the faculty of Jewish studies in Lund invited the then newly-established Paideia, the European Institute for Jewish Studies, to a workshop on a rabbinic text. I remember a full classroom with international students engaged in heated discussions. Someone even played the accordion... In the evening we were all invited to a faculty member's private home, where he and his family had prepared a kosher meal for us. This social gathering was an important event for me: we numbered perhaps forty undergraduates and senior researchers who all believed Sweden would be a potential centre for Jewish studies in the future.

After my year in Lund, I continued with classic and modern Hebrew at the department of Linguistics and Philology at Uppsala University, where I later earned my MA degree with modern Hebrew as the main subject. The establishment of a professorship in Hebrew at Uppsala University dates back to I 605 (Norin 2006: 7-I I), and the long history of scholarship in the discipline is well reflected in the wide range of second-cycle courses that span from an introduction to West Semitic epigraphy to courses in modern Hebrew literature.

At this point I had acquired the linguistic and philological tools that enabled me to work with different strata of Biblical Hebrew, as well as texts in rabbinic and in modern Hebrew.

But where to turn if I wanted to continue with studies in rabbinic literature? After all, as a student in Sweden, I was - to use the laconic expression used by Vibeke Kielding Banik - on the 'periphery of the diaspora' of Jewish Studies, far away from the academic hotspots of Israel and the US. I recalled the workshop in Lund with Paideia, in Sweden. Could it be that this northern corner of the diaspora had become something of a centre for Jewish studies? My first visit to Paideia proved that it was indeed possible for me to study with some of the most renowned scholars from influential institutions of Jewish studies worldwide, without even having to leave my home town of Stockholm. I was accepted as a Walter Benjamin fellow at Paideia in 2009 and joined a classroom with students from Argentina, Armenia, Germany, Hungary, Israel, Italy, Lithuania, Macedonia, Moldova, Poland, Romania, Russia, Spain, Sweden, the UK and Ukraine. The course list of the one-year Walter Benjamin fellowship programme reveals that the student is guided through ancient and contemporary Jewish textual sources by faculty based in academic settings for Jewish studies in the US, Israel and Europe. During an academic year, me and my fellow students completed the following courses (the Paideia One-Year Jewish Study 
Programme for 2009/2010): 'Major themes in the Pentateuch'; Midrashic literature'; 'The Rhythm of Jewish life'; 'Early Kabbalah and its origins'; 'Cultural encounters between Judaism and Islam in the Middle Ages'; 'Religious beliefs in Jewish philosophy of the Middle Ages'; 'Modern Jewish identity'; 'Medieval Halakhah'; 'Introduction to Jewish-Christian relations'; 'Modern Hebrew literature'; 'Jewish theatre'; 'The Jewish society in the modern era'; 'The Hasidic path'; 'Modern Jewish philosophy'. In addition to these courses, modern Hebrew was taught at three different levels for four hours per day during the entire academic year, and there was also a year-long Talmud course.

When I graduated, Paideia was just about to start a joint Master's programme in Jewish civilizations with the Hochschule für Jüdische Studien in Heidelberg (HFJS). Today a Paideia student can chose to combine the year in Stockholm with studies in Heidelberg for a total of r 20 ECTS: 60 credits at Paideia and 60 credits at HFJS. After my Paideia experience I spent a year of graduate Bible studies at the Rothberg International School of Hebrew University and after that, I came back to Uppsala to write an MA thesis on the Tannaitic reception of a certain passage in Exodus, a subject that I could pursue within the realm of Hebrew Bible exegesis. So, after oscillating between classical and modern Hebrew, Jewish studies and Hebrew Bible studies, I found a field where I can make use of the entire spectrum of my educational background.

My educational trail has obviously been both long and winding, and I have often moved in order to continue with Jewish studies at the next level. Individuals have advised me to enrol onto a certain course or programme, but it is not until recently that I have experienced any joint efforts to coordinate existing platforms for Jewish studies in Sweden. As a former student, I want to suggest that the existing institutions jointly draw up possible curricula for students wanting to pursue any kind of Jewish studies, whether it is in the field of history, languages, religion, literature, thought, society, politics or culture.

\section{What can be said about the 'identity' of Jewish studies in Sweden?}

I like to suggest that the 'identity' of a discipline is created by the scholars active in the field, and the networks they are engaged in. It is the sum of the scholarly activity that attracts students to a certain academic setting. The diversity of disciplines that can be associated with Jewish studies poses a special challenge for the 'identity' of the research area: if different fields of Jewish studies could be gathered under one roof, which faculty is then best suited as an academic environment for Jewish studies? Now, it is not far-fetched to assume that scholars and students interested in Zionism and contemporary Jewry might 
not be motivated to study early rabbinic literature, and vice versa. The area of Jewish studies has a mixed pool of potential students amongst aspiring historians, theologians, linguists, law students etc. How to grasp and communicate the 'identity' or, rather 'identities' of disciplines so diverse?

In 2012 the Faculty of Theology at Uppsala University appointed a board to run the multi- and cross-disciplinary Forum for Jewish Studies (FJS), that aims at promoting, supporting and coordinating research and teaching in Jewish history, religion, languages and culture (Instruction for the Forum for Jewish Studies). FJS collaborates closely with other forums, departments, universities and networks and runs a seminar that circulates around the different departments. During the spring semester of $20{ }_{5}$, FJS is announcing eleven seminars at six different departments (FJS seminar programme). As a nomadic organization, the FJS enables an exploration of all the variants of Jewish studies without being limited by disciplinary boundaries. But what if the curricula of Jewish studies were to be developed in Sweden? What if students could obtain a doctoral degree in Jewish studies in Sweden? Then, all of a sudden, we must decide on which institutional framework Jewish studies belongs to. If no separate academic setting can be established to embrace the various fields of Jewish studies at all levels in Sweden, then the field, or at least a delimited part of it, must be 'housed'by an already-existing faculty. Which one? In my opinion, this is a question of identity rather than administration. Which identity will Jewish studies reflect if it is offered as a track within Oriental studies at the department of Linguistics and Philology? Or if it is given within the history of religion in the Faculty of Theology? Or, say, within Hebrew Bible exegesis? The localization of Jewish studies within a university is an important identity marker for the field.

This said I want to address the fact that a majority of the contributors to the volume at hand, myself included, come from faculties of religion and theology. It is indeed problematic to view Jewish studies as primarily the study of Judaism. Nevertheless an important field of Jewish studies, that is in-depth studies of the textual sources of Judaism demand knowledge in (for example) Israelite religion, biblical Hebrew, Koine Greek, exegesis, the Dead Sea scrolls and the history of late antiquity - expertise you usually find at a faculty of theology. Allow me therefore to take a minute to ponder the identity of Jewish studies within the framework of the Faculty of Theology at UU.

In recent years a number of initiatives have been taken towards a more inclusive terminology within Hebrew Bible exegesis at the theology department at Uppsala University and its scholarly networks. The ethnocentricity of the dating system $f . K r$. (BC) and e.Kr. (AD) is often replaced by f.vt. (BCE) and 
v.t. (CE) and the discussions occasioned by this increased cultural sensitivity, can, in the words of Martin Jaffee 'at the very least, remind us of the way that that all temporal schemas represent an index of cultural values' (Jaffee 2006: 2).

Furthermore, the question about what to call the research discipline usually known as Old Testament (OT) Exegesis was the focus in Göran Eidevall's installation speech, as he became a professor of OT Exegesis at Uppsala University in 20I2. Eidevall suggested a name change and the discipline now goes under a parallel usage of Old Testament/Hebrew Bible Exegesis. In addition to this reform, the criteria for applications for $\mathrm{PhD}$ positions changed: before 2012 students needed studies in the New Testament in order to be considered, whereas today Talmud studies serve as an adequate alternative. Also, through FJS, the Faculty of Theology now cooperates closely with Paideia, inviting members of their faculty to lecture in Jewish studies. All these initiatives are vital to pave the way for the establishment of a chair in Talmud studies at the Faculty of Theology at UU, as has been suggested by Lena Roos (20 I 5 ). If a field of Jewish studies is to be introduced in a faculty with a long history of a Christian orientation, then it must be conducted in its own right, not used merely as a springboard to studies of Jesus and the early Jesus movement. The increased sensitivity concerning terminology and dating systems is an important development in this direction.

What are the challenges for the identity development of Jewish studies at a faculty of theology in Sweden? Well, for many, the title 'theology' refers to research conducted in a Christian context. In personal correspondence with Chaim Milikowsky, a leading expert on textual criticism of rabbinic literature at Bar Ilan University, I received the following answer concerning my wish to pursue a doctoral degree in Jewish studies at the Faculty of Theology at UU:

I do hope that students can study Jewish Studies at Uppsala soon, but is indeed the Faculty of Theology the optimal place for this to happen? Where, for example, would one study Buddhism or Islam? If indeed, the answer is the Theology Faculty [ sic], then it must be assumed that Jewish studies belongs there also, but if not, then the German example indicates clearly that Jewish studies in Europe thrives better outside of a Theology Faculty [sic]. (Chaim Milikowsky in e-mail correspondence with Natalie Lantz, 2 I.10.2014)

I quote this e-mail in order to argue that the very name of the faculty creates confusion about what kind of research is conducted there and calls for a justification as to why Jewish studies have a natural place within the framework 
of such a faculty. Will people - even from the scholarly world - perceive me as a priest if I present them with a degree from a faculty of theology? And, on a personal note: what does that imply for my Jewish identity?

Further, in the era of non-confessional theological research I'd like to quote a recommendation letter that the Chief Rabbi Emeritus Morton Narrowe wrote for me considering future studies in the field of Bible studies in a Swedish university setting:

I emphasize [Natalie's programme on biblical idioms in everyday speech at the Jewish Museum in Stockholm 2009] mainly to illustrate what the presence of a Jewish Bible scholar could contribute, not only to the academic world in this country, but uniquely, to Swedish Jewry. [Natalie] might attract others in our communities to Biblical Studies. (Morton Narrowe, in a recommendation letter for Natalie Lantz, I 2.I.20 I I)

I had hoped that Rabbi Narrowe would write something impressive about my skills, but no, instead he highlighted the fact that I am Jewish and affiliated to the Jewish community in Sweden. Rabbi Narrowe called for increased reciprocity between academia and the Jewish community in Sweden. His request corresponds to the current initiatives taken in order to cater to the educational need for Swedish Muslims at Uppsala University, namely the establishment of the first Swedish professorship in Islamic theology and philosophy at the Faculty of Theology in $20 \mathrm{I} 2$.

The press release announcing this initiative, clearly expressed the objective to provide education also for minority groups in Sweden:

Today we have a large community, almost half a million people, with a Muslim background [in Sweden]. We want to change the fact that in the current situation they must travel abroad in order to study, for example, Islamic philosophy, Quranic studies and Islamic law ... An important objective is to offer future leaders or teachers within Swedish Muslim organizations an opportunity to attain academic education in Islamic theology and philosophy at home. (Press release announcing the first Swedish professorship in Islamic theology and philosophy, 8. I I.20 I 2)

It is still too early to analyse the effect of this establishment on the diversity of the student body, but the initiative is vital in order to offer other communities in Sweden training for their professional lives in religious and cultural organizations. Lena Roos notes that 'the students preparing for service in the 
church are but one group in a much more diverse student body' (Roos 2015) at the Faculty of Theology in Uppsala. However, these students are united by their ambition to prepare for service in the church, and thus, I dare argue, still constitute a critical mass that influences the identity of the faculty.

\section{Can a degree in the discipline of choice also lead to a career outside the academic framework?}

Let me now return to my journey through Jewish studies in Sweden and take a minute to stress the importance of updated 'reality checks' for academic institutions that send students out to a labour market that does not exactly demand an expert on, say, West Semitic epigraphy or Ladino... .

A scene from my life as an MA student in Hebrew: I was in a professor's office, taking an exam on a text by Agnon, when the telephone rang. The professor picked up and explained to the caller that no one in the faculty had any time whatsoever for translations of Hebrew fiction. Luckily for me I was able to make out the identity of the caller. That rejected assignment became the impetus for my enrolment onto a course in publishing and translation studies at Stockholm University (SU) and, years later, I contacted the editor that had called the professor and asked for a translator. Today I work as a translator for that very publishing house.

Having done some additional courses in cultural management at SU, with a few months of internship at a museum, I got a job at the Jewish Museum in Stockholm, where I was responsible for PR and public events. Today I am combining the translation assignments with event planning as a freelancing cultural producer. Without the courses and the internships provided at SU I would not have had any work experience corresponding to my educational background at all.

As a former student of Jewish studies, I can vouch for the difficulty of promoting oneself on the labour market. I had to find additional courses for applied training in publishing and cultural management in order to turn my educational background into a competitive resource.

In my opinion, job prospects and practical reasons for a degree in Jewish studies should be discussed at the very first meeting with a potential student. Otherwise the only key to a career is to develop a habit of eavesdropping. 


\section{Conclusion}

This essay is based on my own educational and professional experience as a student of Jewish studies based in Sweden. By demonstrating how I accomplished the arduous task of patching together my own educational trail from a variety of courses offered by different institutions, I addressed the question of how to compose a curriculum that leads to doctoral studies. Sweden may lack the infrastructures that institutes specialized in Jewish studies have in order to follow the students through programmes designed to progress from the basic level to a doctoral level. However, in Sweden there are many academic disciplines leading to the doctoral level that could go under the generic title 'Jewish studies'. Based on these existing, but scattered, courses in Jewish studies in Sweden, my recommendation is to increase joint efforts to coordinate these platforms and draw up possible curricula for students wanting to pursue any kind of Jewish studies from the basic to the doctoral level. Assuming that no separate academic setting can be established to embrace the various fields of Jewish studies at all levels in Sweden, then the field, or at least a delimited part of it, must be housed by an already existing faculty. In my article I argue that this is a question of the field's identity rather than its administration. Notwithstanding the problems of categorizing Jewish studies as primarily the study of Judaism, there are certain benefits that go with placing a curriculum within faculties of religion and theology. In Sweden, however, such faculties have a long history of a Christian orientation. In line with the recent initiatives within Hebrew Bible exegesis at the department of Theology at Uppsala University, I recommend an active sensitivity concerning terminology in order to open the door to a more diverse body of students and scholars wanting to engage in Jewish studies in a faculty of religion and theology in Sweden. Jewish studies must be conducted in its own right, not used merely as a springboard to studies of the early Jesus movement and the New Testament.

Another point of discussion I raise in the article at hand is the question of whether a degree in Jewish studies can lead to a career also outside the academic framework? As a former student of Jewish studies with a patchwork-like degree from different universities, I note the difficulty of promoting oneself on the labour market. I had to find additional courses for applied training in my areas of interest in order to turn my educational background into a competitive resource.

Hence, if curricula of Jewish studies were to be developed in Sweden, it is vital that the issue of job prospects also outside the academic framework is discussed at the very first meeting with a potential student. 
Natalie Lantz, MA, is a doctoral student in Hebrew Bible exegesis at Uppsala University. In addition to her MA degree in Hebrew Bible exegesis, she holds an MA in modern Hebrew and is an alumna of Paideia - the European Institute for Jewish Studies. Her research focuses on developing and exploring a methodological approach for a comparative analysis of the concept of God in the Dead Sea scrolls and early rabbinic literature. Her research interests include Jewish history in late antiquity, rabbinic literature and early Jewish mystical traditions, as well as Semitic philology. Natalie Lantz is an appointed board member of the Forum for Jewish Studies at Uppsala University. Besides her academic work, Natalie Lantz works as an independent literary translator of Modern Hebrew fiction into Swedish and a cultural producer of seminars on Modern Hebrew fiction, rabbinic literature and Hebrew Bible exegesis.

\section{References}

\section{Websites}

Instruction for Forum for Jewish Studies, 201 5 , <http://www.teol.uu.se/ digitalAssets/236/236277_3instr-f--r-forum-f--r-judiska-studier-rev.pdf> (accessed 26.2.2015)

Press release announcing the first Swedish professorship in Islamic theology and philosophy ('Sveriges första professor i islamisk teologi på plats i Uppsala'), 8. I r.20 I 2, $<$ http://www.uu.se/press/pressmeddelanden/pressmeddelandevisning/?id= 1825 \&area $=3,8$ \&typpm\&lang=sv $>($ accessed 9.12 .2015$)$

Seminar programme Forum for Jewish Studies, <http://www.teol.uu.se/digitalAssets/2 36/236259-3seminarieprogram-fjs-vt I 5.pdf > (accessed 26.2.201 5)

The Paideia One-Year Jewish Studies Program 2009/2010 (course list), 201 5 , <http://www.paideia-eu.org/wp-content/uploads/20 1o/o3/Text-CoursesInvitation-2009-2010.pdf> (accessed 26.2.2015)

\section{Bibliography}

Jaffee, Martin, 2006. Early Judaism: Religious Worlds of the First Judaic Millenium (Bethesda, University Press of Maryland)

Norin, Stig, 2006. 'Hebreiska i 400 år', Svensk exegetisk årsbok, 7 I, pp. 7-I I

Roos, Lena, 20 I 5 , forthcoming. 'Gottlieb Klein and the study of religions in Sweden' in Deutsch-jüdische Emigration nach Schweden, ed. L. M. Andersson et al. (Berlin, De Gruyter) 